\title{
A perspective on the widening gap between Covishield vaccine doses in India Lalithambigai Chellamuthu ${ }^{1}$, Sinthu S Sarathamani ${ }^{2}$, Abhijit V Boratne ${ }^{3}$
}

${ }^{1}$ Assistant professor, Department of Community Medicine, Mahatma Gandhi medical College and Research Institute, Puducherry; ${ }^{2}$ Assistant professor, Department of Community Medicine, Mahatma Gandhi medical College and Research Institute, Puducherry; ${ }^{3}$ Professor \& Head, Department of Community Medicine, Mahatma Gandhi medical College and Research Institute, Puducherry

\section{Corresponding Author}

Dr Abhijit V Boratne, Professor \& Head, Department of Community Medicine, Mahatma Gandhi medical College and Research Institute, Pillaiyarkuppam, Puducherry - 607402

E Mail ID: abhijitboratne@gmail.com

\section{Citation}

Chellamuthu L, Sarathamani SS, Boratne AV. A perspective on the widening gap between Covishield vaccine doses in India. Indian J Comm Health. 2021;33(3):541-542. https://doi.org/10.47203/IJCH.2021.v33i03.026

Source of Funding: Nil Conflict of Interest: None declared

\section{Article Cycle}

Received: 17/05/2021; Revision: 05/07/2021; Accepted: 11/09/2021; Published: 30/09/2021

This work is licensed under a Creative Commons Attribution 4.0 International License.

\section{Abstract}

The Oxford University-AstraZeneca's vector-based vaccine called Covishield (ChAdOx1 nCoV- 19 Vaccine) is being manufactured and distributed by Serum Institute of India (SII). National roll out of this vaccine was in a phased manner starting from 16th January 2021. At present, many states are facing shortage of vaccines. Government of India kept changing its policy on dosing gap of Covishield vaccine based on researches. The latest recommendation citing "real-life evidence" from the UK is to extend the two doses of Covishield to 12-16 weeks. This reasonable approach will not only a breathing space for the government but also aids in free up doses for a larger number of people to get their first dose of the vaccine.

\section{Keywords}

Covishield; Serum Institute of India; Vaccine Shortage

\section{Introduction}

The Oxford University-AstraZeneca's vector-based vaccine called Covishield (ChAdOx1 nCoV- 19 Vaccine) is being manufactured and distributed by Serum Institute of India (SII). The vaccine is given intramuscularly with a course of two doses (4-6 weeks apart), containing $0.5 \mathrm{ml}$ each dose. (1) National roll out of this vaccine was in a phased manner starting from 16th January 2021. Initially, only the healthcare and frontline workers received the vaccines, followed by civilians aged $\geq 60$ years with co-morbidities and then later, individuals $\geq 45$ years without comorbidities were also included. Now, the vaccines are being administered to all adults $\geq 18$ years of age. $(1,2)$ This article gives a perspective on the extending gap between Covishield vaccine doses.

\section{Vaccine regimen followed in India}

As of now, over 17.7 crore people have been vaccinated with either Covishield or Covaxin (manufactured by Bharat Biotech Limited), out of whom over 3.9 crore have got the second dose. (3) Covishield accounts for 90 per cent of the 17.7 crore vaccine doses administered so far. The second dose of Covishield was to be received 4-6 weeks after the first, and the second dose of Covaxin was to be taken 28 days after the first, according to the initial permission granted by the Drug Controller General of India (DGCI). $(4,5)$ Based on clinical trials, the interval was later increased to 6-8 weeks for Covishield and 28-42 days for Covaxin by April 2021. (6) At the moment, combining two different doses of vaccine is not allowed. Both Covishield and Covaxin generated immunological responses, with 79.3\% showing seropositivity after the first dose, according to a pan-India study "The Coronavirus Vaccineinduced Antibody Titre (COVAT)." Covishield vs Covaxin recipients had a responder rate of $86.8 \%$ vs $43.8 \%$ and had a median (IQR) rise in anti-spike antibody of 61.5 vs 6 $\mathrm{AU} / \mathrm{ml}$, both $\mathrm{p}-$ value $<0.001$ respectively. (7)

\section{Widening gap between two doses of Covishield}

The National Technical Advisory Group on Immunization (NTAGI) proposed in May 2021 that the period between two Covishield doses be extended to 12-16 weeks, citing "real-life evidence" from the United Kingdom. Covishield dosage intervals have been widened for the second time in the past 3 months, and the move has sparked outrage, 
as a cover-up for vaccine shortage in India. $(4,8)$ The AZD1222 vaccine (marketed as Covishield and Vaxzevria) shows an efficacy of $63.09 \%$ against symptomatic SARSCoV-2 infection. Longer dose intervals of 8 to 12 weeks are attributed to greater vaccine efficacy up to $90 \%$. (9) When the UK government had faced with an increase in cases due to a new SARS-CoV-2 variant B.1.1.7, the decision had been made to keep the vaccine doses apart by up to 12 weeks. The logic behind this is that giving more individuals the first dose sooner will result in fewer deaths and less pressure on the country's already overburdened healthcare system. (8) India's policymakers are pressing ahead with a similar predicament, in which vaccines availability are limited with a capacity gap of 120 million doses till December 2021 and the mortality due to covid19 reaches 4,000 every day. $(8,10)$

Finding from a recently published trial based on 17,178 participants from the UK, Brazil, and South Africa, reported that the vaccine's efficacy increased from $55.1 \%$ (when two doses are given $<6$ weeks apart) to $81.3 \%$ when the interval is extended to $\geq 12$ weeks. (11) Furthermore, the Serum Institute of India has recommended a 12-week interval to achieve vaccine efficacy of $90 \%$. (5)

\section{Conclusion}

Government of India kept changing its policy on dosing gap of Covishield vaccine based on clinical research amid a crippling shortage of vaccines. This should not be referred as cover-up for fixing vaccine shortage. Moreover, it is considered wise to propose changes in the current strategy according to the evolving newer evidences. Any health care system will take its own time to understand the new disease. The current advice to extend the interval between Covishield vaccine doses will not only provide some buffer time to face the growing vaccine demands, but it will also aid in free up doses for a larger number of people to get their first dose of the vaccine. Thereby, this might be regarded a reasonable approach for saving more people from COVID-19.

\section{References}

1. Serum Institute of India. FACT SHEET FOR VACCINE RECIPIENT [Internet]. 2021 [cited 2021 May 14]. Available from: https://www.seruminstitute.com/pdf/covishield_fact_sheet.pdf
2. Covid-19 vaccination in India Day 1: Over 1.9 lakh people inoculated, says govt [Internet]. mint. 2021 [cited 2021 May 14]. Available from: https://www.livemint.com/news/india/covid19vaccination-in-india-day-1-over-1-6-lakh-people-inoculated-3-351sessions-held-says-govt-11610804057599.html

3. Shampa sen. DNA Explainer: What happens if you take one shot of Covaxin and the other of Covishield? DNA Web team [Internet]. 2021 [cited 2021 Jul 23]; Available from: https://www.dnaindia.com/explainer/report-dna-explainer-whathappens-if-you-take-one-shot-of-covaxin-and-the-other-ofcovishield-2890449

4. Extended gap between 2 doses of Covishield reasonable approach: Anthony Fauci [Internet]. mint. 2021 [cited 2021 May 14]. Available from: $\quad$ https://www.livemint.com/news/india/extended-gapbetween-2-doses-of-covishield-reasonable-approach-anthonyfauci-11620956469530.html

5. Covishield $90 \%$ effective if doses given after gap of 2-3 months: Adar Poonawalla [Internet]. [cited 2021 May 14]. Available from: https://www.businesstoday.in/coronavirus/covishield-90effective-if-doses-given-after-gap-of-2-3-months-adarpoonawalla/story/435843.html

6. Explained: When to take your vaccine shot(s) if infected with Covid19, and if not [Internet]. The Indian Express. 2021 [cited 2021 May 14]. Available from: https://indianexpress.com/article/explained/explained-when-totake-your-jabs-if-infected-and-if-not-7312737/

7. Singh AK, Phatak SR, Singh NK, Gupta A, Sharma A, Bhattacharjee $\mathrm{K}$, et al. Antibody Response after First-dose of ChAdOx1-nCOV $\left(\right.$ CovishieldTM $^{\circledR}$ ) and BBV-152 (CovaxinTM ${ }^{\circledR}$ ) amongst Health Care Workers in India: Preliminary Results of Cross-sectional Coronavirus Vaccine-induced Antibody Titre (COVAT) study. medRxiv [Internet]. [cited 2021 May 14]; Available from: https://www.medrxiv.org/content/early/2021/04/13/2021.04.07. 21255078

8. Explainer: Will Extending Gap Between Two Covishield Doses Help Save More People? [Internet]. Moneycontrol. [cited 2021 May 14]. Available from: https://www.moneycontrol.com/news/business/companies/expla iner-will-extending-gap-between-two-covishield-doses-help-savemore-people-6890351.html

9. ITWDN, 2021 UPDATED. Oxford vaccine $90 \%$ effective if doses given 2-3 months apart: Adar Poonawalla [Internet]. India Today. [cited 2021 May 14]. Available from: https://www.indiatoday.in/coronavirusoutbreak/story/covishield-oxford-covid-vaccine-90-effective-2-3months-apart-serum-institute-adar-poonawalla-1787597-2021$\underline{04-06}$

10. Manavi Kapur. India's lofty vaccination goal rests on supplies that may or may not turn up. [Internet]. Quartz India.2021 [cited 2021 Jul 23]; Available from: https://qz.com/india/2013630/will-indiahave-enough-covaxin-and-covishield-doses-by-december/

11. Hung IFN, Poland GA. Single-dose Oxford-AstraZeneca COVID-19 vaccine followed by a 12-week booster. The Lancet. 2021;397(10277):854-5. 